Marquette University

e-Publications@Marquette

4-1-2015

Distant yet Near: Promoting Interdisciplinary Learning in Significantly Diverse Teams through Socially Responsible Projects

Monica Adya

Marquette University, monica.adya@marquette.edu

Bryan Temple

Glasgow Caledonian University

Donald M. Hepburn

Glasgow Caledonian University

Accepted version. Decision Sciences, Vol 13, No. 2 (April 2015): 121-149. DOI. (C) 2015 Wiley. Used with permission. 


\title{
Distant yet Near: Promoting Interdisciplinary Learning in Significantly Diverse Teams through Socially Responsible Projects
}

\author{
Monica Adya \\ Management Department, Marquette University \\ Milwaukee, WI \\ Bryan Temple \\ Retired from Glasgow Caledonian University in Scotland \\ Donald M. Hepburn \\ School of Engineering and Built Environment at Glasgow \\ Caledonian University \\ Glasgow, Scotland
}

\begin{abstract}
With global specialization of work units within organizations, interdisciplinary work practices comprised of collaborative efforts between technical and business teams are increasingly common in today's workplace. While higher education has responded by creating opportunities for remote teams to learn from collaborative work, occasions for interaction between remotely situated significantly diverse teams such as business and engineering are few. This study describes a pedagogical offering between
\end{abstract}


NOT THE PUBLISHED VERSION; this is the author's final, peer-reviewed manuscript. The published version may be accessed by following the link in the citation at the bottom of the page.

U.S.- based business teams and U.K.-based engineering teams that delivers such an experience around mutually dependent, socially responsible projects. Results from student surveys and reflections confirm that the pedagogical design is able to generate perceived interdependence between these diverse teams. Student responses to surveys also suggest that the collaboration is effective in raising student confidence in interdisciplinary and remote team work among students. The study concludes with recommendations for transferability and actualization of interdisciplinary collaboration.

\section{Introduction}

As firms emphasize internal efficiencies through cross-functional collaboration and core competencies, they engender increased expectations that higher education will prepare students to be able to contribute to firms' bottom-line immediately upon employment. Enterprise-wide initiatives are driving greater functional integration and use of multidisciplinary project teams (Barki \& Pinsonneault, 2005). Furthermore, in choosing to focus on core competencies, organizations are outsourcing functions not considered central to their mission (Arnold, 2000). The result is a greater global distribution of work, as evident in offshoring of manufacturing and software development. Remote multidisciplinary teams, therefore, are common and essential in today's workplace. Considering these trends, market forces are placing greater demands on institutions of higher education to create pedagogical opportunities that expose students to collaborative, multidisciplinary work practices.

While numerous examples of classroom-based remote team projects exist (e.g., Adya, Nath, Sridhar, \& Malik, 2008; Long \& Carlo, $\underline{2013}$ ), examples of collaborations between remote multidisciplinary teams are few, and there are even fewer between significantly diverse teams, such as those from business and engineering (e.g., Long, Moos, \& Bartel-Ridic, 2012; Temple \& Allen, 2000). Such teams must not merely foster trust, effective communications, and productive relationships, but understand the synergies and incongruities of each other's disciplines, all via technology mediation. While graduate students often obtain such experiences through professional engagements, these opportunities are limited for undergraduate students, who must typically rely on in-class or internship-/co-opbased experiences.

Decision Sciences, Vol 13, No. 2 (April 2015): pg. 121-149. DOI. This article is (C) Wiley and permission has been granted for this version to appear in e-Publications@Marquette. Wiley does not grant permission for this article to be further copied/distributed or hosted elsewhere without the express permission from Wiley. 
NOT THE PUBLISHED VERSION; this is the author's final, peer-reviewed manuscript. The published version may be accessed by following the link in the citation at the bottom of the page.

This study describes an interdisciplinary pedagogical initiative between U.S.-based business students and U.K.- based engineering students, designed to prepare these undergraduate students for the challenges of current and future work environments. Three aspects of this offering make it unique: the collaboration is between significantly diverse teams whose disciplines are very different but mutually synergistic; all work is accomplished through technology mediation as the teams are remotely situated; students have a common goal of creating a socially responsible product. It is important to differentiate between multidisciplinary and interdisciplinary work. Rosenfield (1992) defines multidisciplinary teams as those that work independently in their own disciplines to solve a common problem, and contrasts them with interdisciplinary teams that work jointly, but from their own perspectives, to address this shared issue. Interdisciplinary teams experience greater transformation through collaborative engagement than multidisciplinary teams. More significantly, because such teams are codependent for functional knowledge, cross-disciplinary cooperation can motivate teams toward common goals and project outcomes (Pinto, Pinto, \& Prescott, 1993). As such, the U.S.-U.K. offering described here is interdisciplinary rather than multidisciplinary.

In subsequent sections, we review existing pedagogical literature, highlighting the innovativeness of U.S.-U.K. collaboration. This is followed by a description of the offering and its related outcomes as measured through student surveys and reflective essays. The concluding section provides guidelines and recommendations for transferability to other domains.

\section{Review Of Relevant Literature}

Higher education often provides decidedly specialized contexts for learning (Wojahn, Dyke, Riley, Hensel, \& Brown 2001). While such contextualized delivery is efficacious considering pragmatic constraints of the teaching environment, it often results in compartmentalized knowledge and inefficiencies (Housely, 2003). Interdisciplinary and collaborative learning opportunities are an attempt to overcome such fragmented thinking (Klein, 1995) and "develop holistic modes of inquiry, decision making, and practice" (Housely, 2003, p. 1). Our

Decision Sciences, Vol 13, No. 2 (April 2015): pg. 121-149. DOI. This article is (C) Wiley and permission has been granted for this version to appear in e-Publications@Marquette. Wiley does not grant permission for this article to be further copied/distributed or hosted elsewhere without the express permission from Wiley. 
interest in globally focused, interdisciplinary pedagogy led to an examination of two aspects of existing literature-(i) the disciplinary composition of collaborating teams, and (ii) the context of team work as defined by the nature of joint work, technologies, and other project characteristics. The literature, summarized in Table $\underline{1}$, is by no means exhaustive, but reflects the current state of pedagogy in this domain.

Table 1. Summary of key pedagogical implementations in multidisciplinary remote teams

Study

1. Adya et al. (2008)

2. Chau (2007)

3. Dyke and Wojahn (2000)

4. Ford et al. (2004)

5. Long and Carlo (2013)

6. Long et al. (2012)

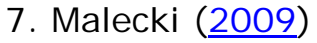

8. Metros (2005)

9. Miller and Olds (1994)

\section{Disciplines Engaged}

Project management and systems analysis and design teams, both in business schools

Subspecialties of engineering

Technical communication and engineering

Business and engineering

Supply chain, facilities design, production

Supply chain in engineering and business

Business and engineering

Visual design and education students

Eight engineering subspecialties

\section{Remote Teams?}

Yes-United System design States, India, projects defined by respectively collaborating faculty

No

Faculty designed sustainability projects

No

Client-based projects

No

Design a novel product and related marketing plan and documentation

Yes-Puerto Design of Rico manufacturing facility

Yes-France, Compare U.S. and United States French supply chain orgs

No Industrially defined collaborative projects

No Design, deliver learning objects for school students, particularly those with disabilities

No Industrial- and government-driven projects 


\section{Study}

10. Newell,

Marchese,

Ramachandran,

Sukumaran, and

Harvey (1999)

11. O'Brien et al $(\underline{2003})$

12. Olson-

Buchanan et al. (2007)

13. Okudan and

Zappe (2006)

14. Ropers-

Huilman et al.

(2005)

15. Rosca (2005)

16. Rusu et al.

(2009)

17. Ryssen an

Goddar (2000)

18. Temple and

Allan (2000)

19. Wellington, Thomas, Powel, and Clarke (2002)

20. Winn and

Heeter, (2006)

21. Wojahn et al. (2001)

22. Zavbi and Tavcar (2005)
Disciplines

Engaged

Engineering and

communications

Civil engineering and

construction teams

Only management

principles

Manufacturing

management and

those in engineering

entrepreneurship

(graduate)

Biomedical

engineering students

Business and

engineering

Software engineering

International

marketing

Business and engineering teams

Engineering, marketing, accounting, and industrial design

Product design and education
Remote Teams?

No

es-United States only

No

No

Two faculty-defined design projects

No

No

(1)

Yes-U.S.-

based

Yes-United

States,

Belgium

Facility design

project defined by

faculty

Unclear

Faculty-designed

open-ended

projects

Service learning

projects

Software development for HR firm

Government-driven design project

Write a term paper analyzing markets

for a particular product

Yes-Europe System design projects defined by faculty

No Industrial-driven projects

No

Design game concepts for students from 7 th to 9 th grades

Industrial- and government-driven projects engineering

No

Engineering Yes-

subspecialties
Faculty-defined

product 
NOT THE PUBLISHED VERSION; this is the author's final, peer-reviewed manuscript. The published version may be accessed by following the link in the citation at the bottom of the page.

\begin{tabular}{|c|c|c|c|}
\hline \multirow[t]{2}{*}{ Study } & \multirow[t]{2}{*}{$\begin{array}{c}\text { Disciplines } \\
\text { Engaged }\end{array}$} & $\begin{array}{l}\text { Remote } \\
\text { Teams? }\end{array}$ & $\begin{array}{c}\text { Nature of } \\
\text { Engagement }\end{array}$ \\
\hline & & $\begin{array}{l}\text { Swiss, } \\
\text { Netherlands }\end{array}$ & $\begin{array}{l}\text { development } \\
\text { projects }\end{array}$ \\
\hline
\end{tabular}

\section{The Disciplinary Composition of Collaborating Teams}

The past decade has seen a steady shift toward multidisciplinary pedagogy that ranges from collaboration between subspecialties of a field, for example, branches of engineering, to significantly diverse teams such as those from the social sciences and engineering. The most common instances have been in the former category, such as Ropers-Huilman, Carwile, and Lima (2005), who used a service learning project with students from two subspecialties of biomedical engineering to impart collaborative problem solving. Similarly, combinations of civil engineering and construction students (O'Brien, Soibelman, \& Elvin, 2003), and product designers, pedagogy experts, and content experts (Winn \& Heeter, 2006) also fall within this category. Adya et al. (2008), Olson-Buchanan, Rechner, Sanchez, and Schmidtke (2007), and Ryssen and Godal (2000) paired business students with differing skill sets. Adya et al. (2008), for example, facilitated collaboration between U.S.-based project management (PM) teams and systems development teams in India. Collaboration between subspecialties are easier to set up as common learning goals can be comfortably established, and collaborating partners are easier to locate due to discipline-based proximity.

Among significantly diverse teams, Ford, Goodrich, and Weissbach (2004) and Okudan and Zappe (2006) paired colocated business and engineering teams to create designs and develop marketing plans for products, while Maleki (2009) had similar teams work on projects from external clients. Long and Carlo (2013) enabled collaboration between supply chain, production planning, and facility layout and design teams at multiple locations. In another interesting implementation, Long et al. (2012) developed a three-way collaboration between supply chain students in engineering and business schools in the United States and France. Although some studies reported higher team conflicts due to interdisciplinary factors (e.g., Winn \& Heeter, 2006), many studies involving significantly

Decision Sciences, Vol 13, No. 2 (April 2015): pg. 121-149. DOI. This article is (C Wiley and permission has been granted for this version to appear in e-Publications@Marquette. Wiley does not grant permission for this article to be further copied/distributed or hosted elsewhere without the express permission from Wiley. 
diverse teams found that teams experienced mutual (O'Brien et al., 2003) and transformative (Metros, 2005) learning.

\section{The Context of Team Work: Remoteness and Project Focus}

Virtual teams have been researched extensively (e.g., Powell, Piccoli, \& Ives, 2004). Few studies, however, have examined virtual teams pedagogically, and when they have, the nature of team engagement has not always been truly remote or interdisciplinary. To illustrate, Olson-Buchanan et al. (2007) used colocated "virtual" teams, situated on the same campus, that were not allowed to meet face-to-face during the project. Adya et al. (2008), Rusu, Rusu, Docimo, Santiago, and Paglione (2009), Ryssen and Godal (2000), and Zavbi and Tavcar (2005), in contrast, implemented international team projects, though not all of these were interdisciplinary or exposed students to face-to-face communications such as video conferencing (VC). In Adya et al. (2008), for instance, remote teams used asynchronous collaborative communications that stymied team accountability.

The nature of collaborative project work varied extensively across the studies reviewed. In most, teams collaborated on facultydefined projects, such as designing a centralized manufacturing facility (e.g., Long \& Carlo, 2013), writing a term paper analyzing markets for a defined product (e.g., Ford et al. 2004), and systems design projects pared down to fit class scope (e.g., Adya et al., 2008). Faculty control on project scope is useful for managing the learning environment, already complicated by multidisciplinary team dynamics. However, the project parameters are often limited and not reflective of real-world complexities. Some educators have relied on projects from external partners to provide a richer learning experience. Maleki (2009) and Rosca (2005), for instance, used industrial projects, while Miller and Olds (1994) relied on government projects for engineering teams. In general, the experiential nature of these offerings seems to be more crucial to learning than the nuances of the project.

Socially responsible projects are effective in creating awareness in students about their role as global citizens. Such projects are also

Decision Sciences, Vol 13, No. 2 (April 2015): pg. 121-149. DOI. This article is (C) Wiley and permission has been granted for this version to appear in e-Publications@Marquette. Wiley does not grant permission for this article to be further copied/distributed or hosted elsewhere without the express permission from Wiley. 
more engaging than traditional academic activities as they present real-world constraints but with a scope that is achievable within the bounds of a semester. In our examination of the literature, we found a relatively small number of collaborative projects centered on social responsibility. For instance, Chau (2007) used faculty-designed projects on sustainability, Ropers-Huilman et al. (2005) used service learning projects, and Metros (2005) developed learning objects for school students, particularly those with disabilities. As Table $\underline{1}$ suggests, no study reviewed all three elements of remote, significantly diverse teams working on socially responsible projects. Figure $\underline{1}$ positions the U.S.-U.K. collaboration within the context of studies reviewed herein.

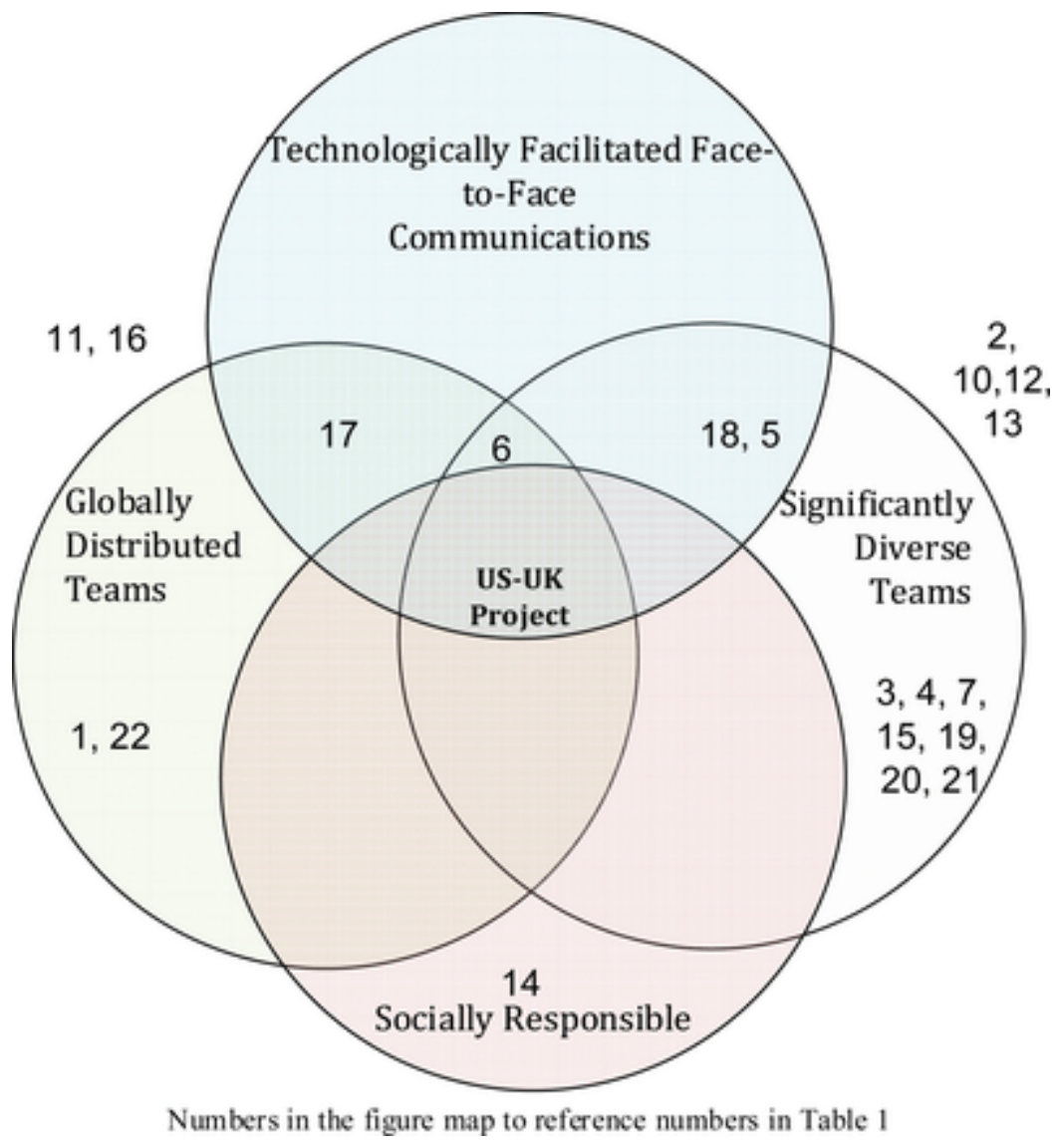

Figure 1. U.S.-U.K. offering at the core of global, socially responsible, and multidisciplinary pedagogy. 


\section{I mplementation Of The U.S.-U.K. Offering}

In 2008, U.S.-business teams and U.K.-engineering teams began collaborating twice a year during Fall and Spring semesters. In 2012 , the offering changed to once a year due to changes at one of the institutions. A total of 71 product designers and 419 engineers in the United Kingdom, and 271 business students in the United States, comprising 63 interdisciplinary teams, have since engaged in this joint offering. U.S. teams are typically comprised of two to four members while U.K. teams have four to six. As presented later, the engagement has been nontrivial as Fall term projects run mid-September to early December and Spring term projects run mid-J anuary to early April.

\section{Nature of the Underlying Projects: Social Responsibility}

In alignment with the authors' institutional missions of servicebased learning, U.S.-U.K. teams engaged in socially responsible projects in both terms. In the Fall term, participants jointly developed a fully costed, viable design for a recreational product or activity for children with disabilities, or differently abled children. Spring term projects involved "green" products that result in energy efficiency, utilize renewable energy sources, or teach sustainable energy concepts to middle-school children. Table $\underline{2}$ summarizes the two offerings.

Table 2. Overview of U.S.-U.K. Fall and Spring projects

Details

Duration

Goal

Product/project requirements

Examples of projects
Fall Offering

Mid-September to early December

Inclusive activity for children with different abilities

(a) Inclusive design for children with different abilities, (b) intellectually stimulating children with different abilities,

(c) non-computer-based activity, and (d) market viability

Connect- 4 style game with eye tracker to control movements

Remote controlled car operable by eye tracking device

\section{Spring Offering}

Mid-J anuary to early April

Renewable or "green" energy products

(a) Easy assembly by target audience, (b) easy to understand user manual, (c) attractive packaging, and (d) market viability

Solar power-heated tents Rechargeable batteries charged by bicycle motion

Decision Sciences, Vol 13, No. 2 (April 2015): pg. 121-149. DOI. This article is (C) Wiley and permission has been granted for this version to appear in e-Publications@Marquette. Wiley does not grant permission for this article to be further copied/distributed or hosted elsewhere without the express permission from Wiley. 
NOT THE PUBLISHED VERSION; this is the author's final, peer-reviewed manuscript. The published version may be accessed by following the link in the citation at the bottom of the page.

Details

Typical market

U.S. team constitution

U.K. team constitution
Fall Offering

United States, United Kingdom, World

Business and project managers

Mechanical engineers

Electrical engineers

Product designers
Spring Offering

United States or United Kingdom

Business and project managers

Mechanical engineers

Electrical engineers

\section{Positive Interdependence among Teams}

Collaborative learning is most effective when teams are positively interdependent (Millis \& Cottell, 1997). Such mutual dependency should promote individual learning and generate a successful collaborative outcome (Johnson, Johnson, \& Holubec, 1998). Positive interdependence can be created in various ways, for example, through task sequencing that makes team members' work dependent upon others, product or goal interdependence whereby task outcomes require unique contributions from each member, or role interdependence in which each team member is assigned a specific role (Foundation Coalition, 2014). As described next, the U.S.-U.K. projects relied on several of these pedagogical elements.

\section{Interdependent Outcomes}

Beyond individual course requirements, U.S.-U.K. teams deliver three shared outcomes for evaluation-(a) a feasible, fully costed design for the product, (b) a companion business case, and (c) a joint presentation pitched to potential investors (faculty and invited guests). Students are asked to consider these deliverables as joint, rather than as having engineering and business components. Table $\underline{3}$ presents a full listing of deliverables expected of the U.S.-U.K. teams. Even deliverables that appear to be independent in this table are not. For example, U.K. members routinely discuss product features with U.S. counterparts to ensure that market viability is not overlooked.

Similarly, U.S. cohorts develop a project schedule that includes the activities of U.K. members. This requires mutual awareness of roles, timelines, and activities. Interdependent work processes, described next, are designed to support these.

Decision Sciences, Vol 13, No. 2 (April 2015): pg. 121-149. DOI. This article is (C) Wiley and permission has been granted for this version to appear in e-Publications@Marquette. Wiley does not grant permission for this article to be further copied/distributed or hosted elsewhere without the express permission from Wiley. 
Table 3. U.S. and U.K. deliverables

U.S. Deliverables

Project management documentation

- Project charter

- Project plan including communications, resource, risk, schedule, quality plans

- Lessons learned and project document updates

- - Weekly agendas and minutes

Course reflection

- Individual-Periodic (1-2 weeks) reflection on team-based and interdisciplinary learning

- - Team-Project lessons learned

\section{U.K. Deliverables}

Product development documentation

- Product ideas

- Product concept

- Refined product

- Drawings of the product

- Manufacturing route/costs

Course reflection

- Individual-End-project reflection on team and interdisciplinary learning

- - Individual-Reflection on technical merit of the product

J oint-Prototype and business case

- $\quad$ Final prototype concept

- Breakeven analysis, payback period, and ROI

Joint-Investor presentation

- - U.K. personnel present product design/manufacture material, questioned on business analysis

- $\quad$ U.S. personnel present business analysis, respond to questions on technical details

\section{Interdependent Work Process}

Complementary skills across U.S.-U.K. members enable highly interdependent work processes (Figure $\underline{2}$ ) and deliverables (Table $\underline{3}$ ). Following a product brief from faculty and initial research on market needs, teams brainstorm product ideas. U.S. members conduct a preliminary market review to map out the competitive space for various product ideas being considered, including typical product features and prices. This information is used to jointly brainstorm ideas during initial VC meetings. The U.S.-U.K. teams use decision criteria to agree on an idea to take forward. The act of identifying product selection criteria often initiates the process of understanding

Decision Sciences, Vol 13, No. 2 (April 2015): pg. 121-149. DOI. This article is (C) Wiley and permission has been granted for this version to appear in e-Publications@Marquette. Wiley does not grant permission for this article to be further copied/distributed or hosted elsewhere without the express permission from Wiley. 
and reconciling disciplinary differences. In subsequent weeks, for the selected product, U.K. members refine the concept, develop mechanical/electrical requirements, and define manufacturing routes. This is iteratively reviewed and evaluated by U.S. members who must give due consideration to marketability and costing. As the product evolves, U.S. personnel assemble the business case to present to potential investors.

US Business Teams

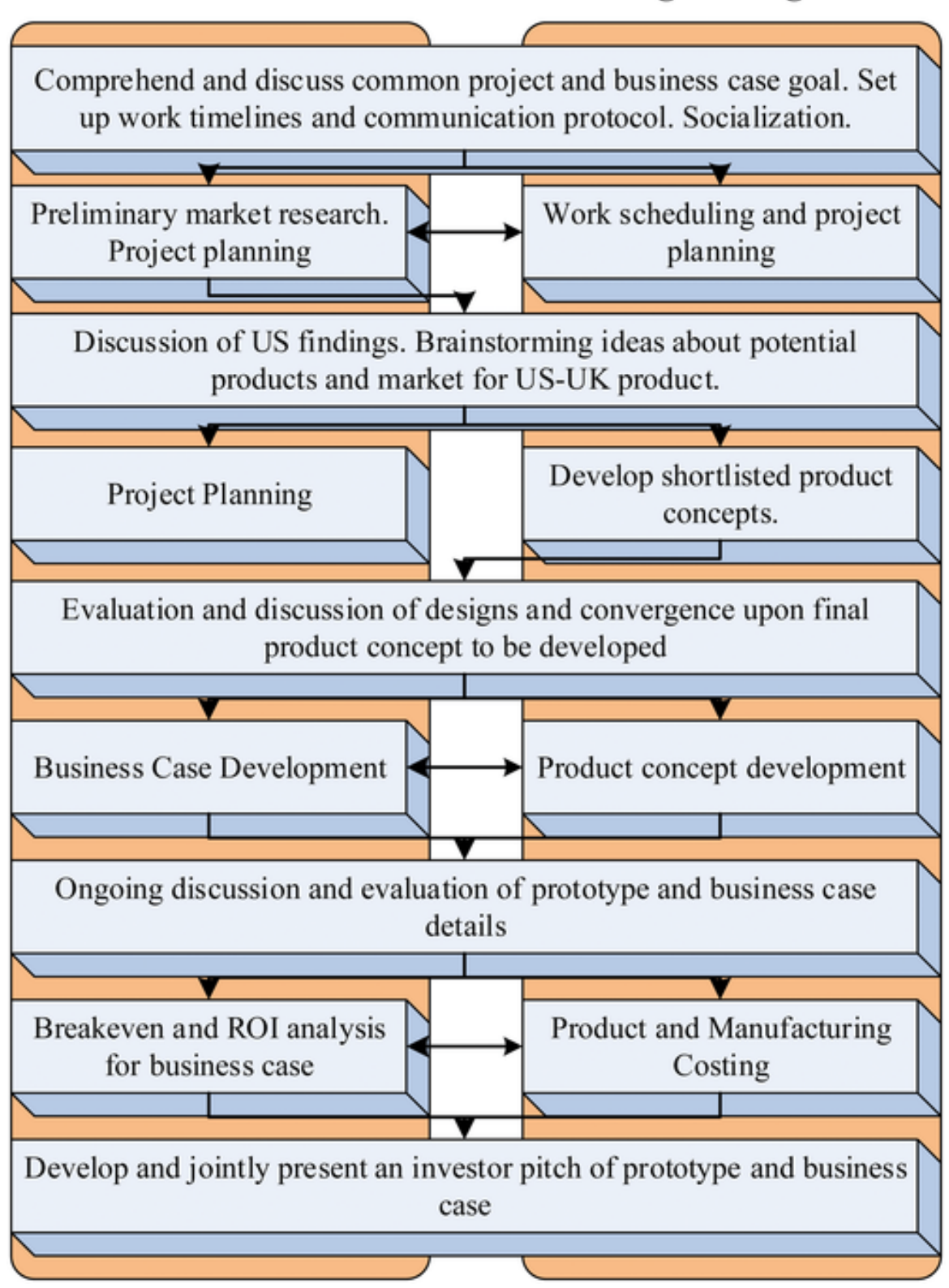

Figure 2. Overview of U.S.-U.K. interactions.

\section{UK Engineering Teams}

Decision Sciences, Vol 13, No. 2 (April 2015): pg. 121-149. DOI. This article is (C Wiley and permission has been granted for this version to appear in e-Publications@Marquette. Wiley does not grant permission for this article to be further copied/distributed or hosted elsewhere without the express permission from Wiley. 
While U.S. members are largely responsible for assembling the business case, they need manufacturing costs from their U.K. colleagues to conduct meaningful costing, pricing, breakeven, and payback analysis. Engineers require product volume and price targets to effectively select materials and manufacturing routes, but this information is not available from their U.S. business partners at the start of the project while they are investigating competitors. The business case also requires a brief product overview, technical specification, and risk analysis that should reflect two aspects, (i) product- and manufacturing-related risks, information that the U.K. team is best suited to provide, and (ii) business risks due to financial fluctuation, production in foreign locations, and logistical considerations, which the U.S. team is best positioned to consider. U.S. team members must routinely evaluate the product, cost, and requirements to ensure market viability. As U.K. team members are partly evaluated on product viability, they depend on U.S. business partners to evolve product features, determine price, and design effective marketing plans. This joint responsibility for exchanging information, which is dependent on different timelines, challenges team interactions and, as expected, gives rise to both positive and negative conflict. Whether the conflict is positive or not, team members gain from reflecting on the process and their actions during the project, which could have altered the outcome.

Joint presentations in the final VC meetings last about 30 minutes, and include product and business case descriptions as well as a Q\&A session. U.K. team members present information on product design and manufacturing while U.S. team members deliver business aspects of the project. Team interactions during the presentation, such as handovers at transitions points, are indicators of how coherent the team is. Postpresentation, teams must be prepared to answer questions related to their international partners' work. Specifically, U.S. faculty ask U.K. engineers business-related questions, such as those related to cost analysis and marketing plans, and engineering faculty query U.S. team members about choices of materials, and electrical, mechanical, and other engineering decisions. Teams are given advance notice of this format and, therefore, should ensure that they are comfortable with the choices made by their partners. To some degree, this allows faculty to ascertain whether interdisciplinary knowledge exchange has occurred, although the presentation, by

Decision Sciences, Vol 13, No. 2 (April 2015): pg. 121-149. DOI. This article is (C) Wiley and permission has been granted for this version to appear in e-Publications@Marquette. Wiley does not grant permission for this article to be further copied/distributed or hosted elsewhere without the express permission from Wiley. 
itself, is not a holistic representation. From the elements described, a lack of knowledge exchange can, however, become evident during the presentation. For instance, in Fall 2011, presentations were cancelled 2 hours prior to delivery (6:00 AM U.S. time) due to an ice storm in Europe. Each team had to deliver the entire presentation without input from their collaborating partners. Teams that routinely engaged with remote partners around their work products were better prepared and able to respond to questions than those that did not.

\section{Interdependent Processes around Communications}

Teams communicate via VC, shared spaces, and e-mail (Figure $\underline{3}$ ). Weekly VC sessions are arranged and mandated by faculty but agendas are left to the participants to establish. Interactions around e-mail and shared spaces are used at the discretion of teams. Typically, U.S. partners e-mail agendas to U.K. 48 hours prior to a VC session, allowing U.K. members to add agenda items up to 12 hours prior to the session. U.S. team members are also responsible for creating minutes of joint meetings and sending them to their U.K. partners within 24 hours of a VC. Agendas and minutes are graded at the end of the term. Beyond this, teams can use other technologies, such as Skype or Google Hangouts, to augment "face-to-face" interactions in their own time; teams often do so close to the delivery of final documents. Students tend to prefer VC interactions, as expected, for brain storming, choosing final products, discussing marketing plan, etc.; shared space is used mostly as a document repository, and e-mails are used primarily for sharing agendas/minutes and reminders or notifications. This use of communication media often evolves from team usage and reflection with little or no faculty directive.

Decision Sciences, Vol 13, No. 2 (April 2015): pg. 121-149. DOI. This article is (C) Wiley and permission has been granted for this version to appear in e-Publications@Marquette. Wiley does not grant permission for this article to be further copied/distributed or hosted elsewhere without the express permission from Wiley. 


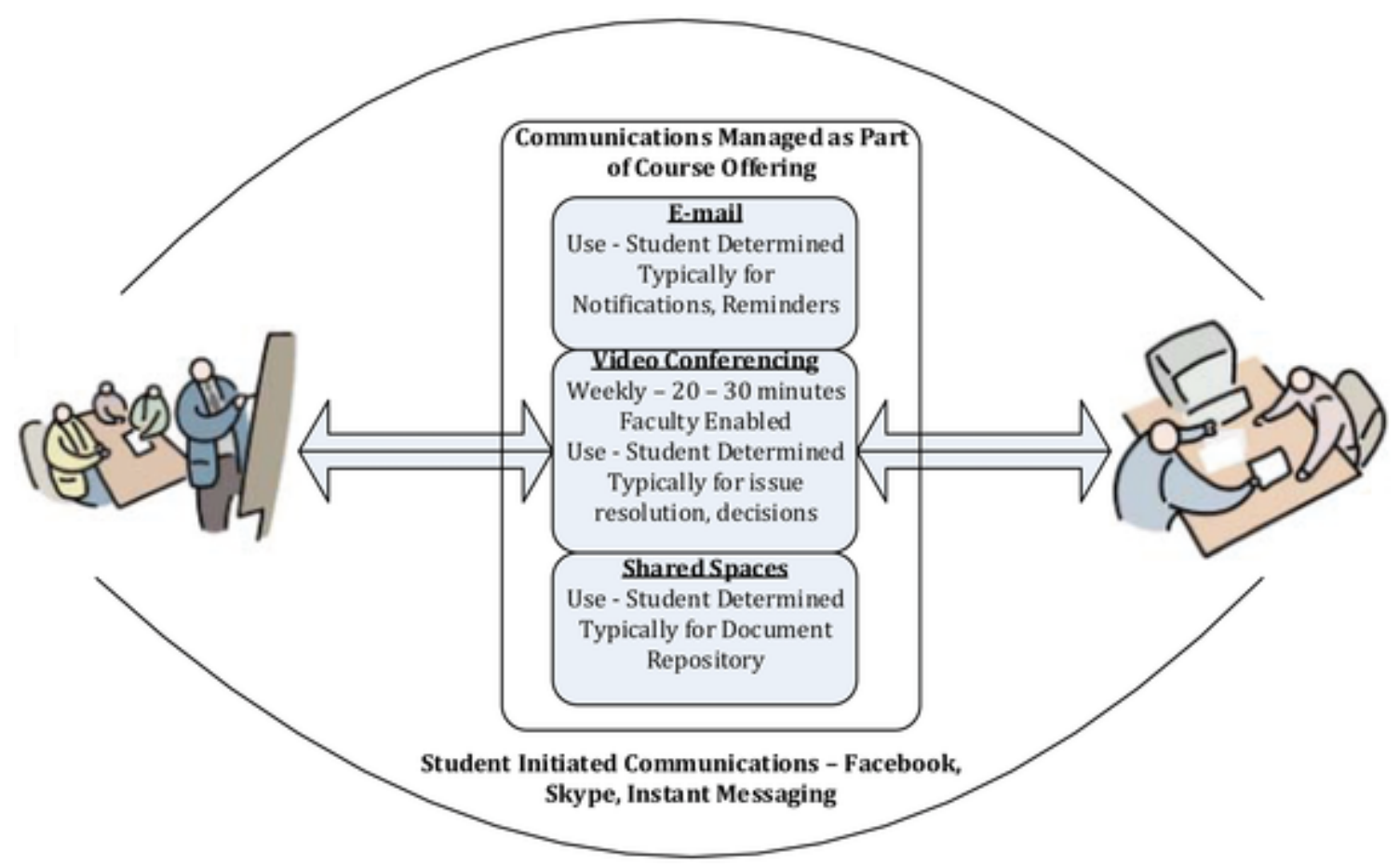

Figure 3. U.S.-U.K. communications.

\section{Controlled Certainty and Deliberate Uncertainty}

A multifaceted learning environment, such as that described here, lends itself well to managed uncertainty. Faculty create a level of surety by providing course structure, imposing challenging but reasonable project constraints, setting up VC communications, and managing consistent communication of goals and processes across the two locations. However, once collaboration begins, group dynamics, interactions, and trust can change unpredictably on a weekly basis. This is particularly so during key stages, such as when agreeing upon a product concept or target market, keeping production costs low while producing a marketable product, and identifying the production volume needed to meet projected demand (affecting manufacturing route and costs). This aspect of student interactions is deliberately left unmanaged to enable active problem solving and engaged learning. Students are tasked with resolving these interdisciplinary tensions. Faculty, they are told, take a consultative role, but students are answerable for team success. They may escalate issues to faculty but must demonstrate at least three prior attempts at issue resolution. 
Most students quickly comprehend the need for active conflict and team management.

\section{Reflective Evaluation and Continuous Evolution}

Both faculty and students engage in periodic reflection (Table $\underline{3}$ ). Every $2-3$ weeks, U.S. students complete an individual reflective assignment wherein they ponder on their own learning, contributions to their U.K. partners' learning, factors that have aided or deterred effective collaboration, and technology facilitation and effectiveness. Additionally, they present three lessons learned during the final week of classes. U.K. teams meet with faculty every week to assess progress and consider next steps. They also submit an end-ofsemester detailed reflection on the overall learning process. These graded reflections provide routine contemplative opportunities to incite team members to consider their actions and adjust behaviors during current/future project execution.

Faculty also benefit significantly from regular discussions that promote continuous improvement. They use VC during the term to resolve ongoing issues, and an end-of-semester debrief to identify improvements for the next offering: student feedback and faculty observations play important roles in this. In a Fall 2010 debrief, it was agreed that the lack of a common business case template impeded the speed with which teams understood the interdependent nature of their work. In response, U.S. faculty created a template that is now followed at both locations. Similarly, in Spring 2012, faculty determined that product costing was one of the more confounding aspects of the project to the joint teams. Business and engineering students understood product costing in different ways, with engineers being more comfortable with direct costing and business students with indirect costs. In response, U.K. faculty developed a presentation and a template for costing that are now used at both locations. Both faculties have thus also benefitted from interdisciplinary engagements. Evolution of the engagement is vital, and a conscious and conscientious commitment to continuous improvement is critical to sustain both the institutional partnership and an effective learning environment. Table $\underline{4}$ shows key improvements from continuous improvement over multiple offerings.

Decision Sciences, Vol 13, No. 2 (April 2015): pg. 121-149. DOI. This article is (C) Wiley and permission has been granted for this version to appear in e-Publications@Marquette. Wiley does not grant permission for this article to be further copied/distributed or hosted elsewhere without the express permission from Wiley. 
NOT THE PUBLISHED VERSION; this is the author's final, peer-reviewed manuscript. The published version may be accessed by following the link in the citation at the bottom of the page.

Table 4. Continuous improvement in U.S.-U.K. offerings

\begin{tabular}{|c|c|c|c|}
\hline \multicolumn{4}{|c|}{ Key Changes Made in Response to Continuous Evaluation } \\
\hline Year & Project & Deliverables & Communication \\
\hline \multicolumn{4}{|c|}{ altems in bold/italics indicate changes from previous year's offerings. } \\
\hline $\begin{array}{l}2008- \\
2009\end{array}$ & $\begin{array}{l}\text { Socially } \\
\text { responsible }\end{array}$ & $\begin{array}{l}\text { Project documentation, } \\
\text { product design }\end{array}$ & $\begin{array}{l}\text { VC and e-mail (no shared } \\
\text { spaces) }\end{array}$ \\
\hline $\begin{array}{l}2009- \\
2010\end{array}$ & $\begin{array}{l}\text { Socially } \\
\text { responsible }\end{array}$ & $\begin{array}{l}\text { Project documentation, } \\
\text { marketing plan with low } \\
\text { level cost analysis, } \underline{a} \\
\text { product design, reflections }\end{array}$ & $\begin{array}{l}\text { VC, e-mail, shared } \\
\text { spacesa (Blackboard) }\end{array}$ \\
\hline $\begin{array}{l}2010- \\
2011\end{array}$ & $\begin{array}{l}\text { Socially } \\
\text { responsible }\end{array}$ & $\begin{array}{l}\text { Project documentation, } \\
\text { business case with } \\
\text { extensive cost analysis, a } \\
\text { product design, } \\
\text { reflectionsa }\end{array}$ & $\begin{array}{l}\text { VC, e-mail, shared } \\
\text { spacesa (Blackboard, } \\
\text { SharePoint) }\end{array}$ \\
\hline $\begin{array}{l}2011- \\
2012\end{array}$ & $\begin{array}{l}\text { Socially } \\
\text { responsible }\end{array}$ & $\begin{array}{l}\text { Project documentation, } \\
\text { business case with } \\
\text { extensive cost analysis, } \\
\text { product design, reflections }\end{array}$ & $\begin{array}{l}\text { VC, e-mail, shared } \\
\text { spacesa (student choice, } \\
\text { e.g., Google+, Box.com, } \\
\text { Dropbox.com) }\end{array}$ \\
\hline
\end{tabular}

2012- Offering has reached steady state

2013

\section{Effectiveness And Contributions Of The U.S.-U.K. Project}

Evaluating effectiveness of learning has been somewhat of a challenge of this joint venture. Traditional university and accrediting assessment focuses on specific course-related learning objectives, often reflected in course deliverables. Finding a common set of deliverables that support disciplinary learning objectives across business and engineering is not easy. While the quality and content of business cases and final presentations provides a measure that follows structured formats and templates, these mostly reflect class requirements and team effort rather than interdisciplinary learning. This is further challenged by the complex nature of team interactions that makes it difficult to separate individual and team, as well as soft and technical, learning. Considering the goals of this collaboration, survey data and class reflections were a better source of assessment. Herein, we were also challenged by the different human subject protocol requirements in the United States and United Kingdom. As such, learning evaluations are presented based on survey data, U.S. reflections, and U.K. reflective essays. Three specific aspects were

Decision Sciences, Vol 13, No. 2 (April 2015): pg. 121-149. DOI. This article is (C) Wiley and permission has been granted for this version to appear in e-Publications@Marquette. Wiley does not grant permission for this article to be further copied/distributed or hosted elsewhere without the express permission from Wiley. 
examined: (a) student confidence in interdisciplinary work, (b) comfort with virtual teams and technologies, and (c) perceived dependency in collaborative projects.

For the last three offerings, business students completed a preand postproject survey. The preproject survey was administered about 3 days prior to the first VC meeting between U.S. and U.K. teams, while the postproject survey was completed about 3 days prior to project completion, that is, the joint VC presentation. Additionally, business students completed five short reflections (R1-R5) during the semester while the engineers completed one large reflective essay upon project conclusion. These reflections asked students to ponder on a range of issues, from the effectiveness of specific technologies being used for collaboration to that of their own management and collaboration style. Some survey questions were embedded within the business students' reflective surveys. Reflections, we found, provided a more holistic view of student experience than surveys.

\section{Student Confidence with Interdisciplinary Collaboration}

In Spring 2013, 36 business students completed pre- and postproject surveys. Responses from two participants were dropped due to incomplete postproject surveys, yielding 34 usable responses. The survey measured, among other things, student confidence in their knowledge of engineering, uncertainty about working with engineering teams, and perceived ability to contribute business knowledge to the project. Specifically, students responded to the following:

Preproject Survey I tems (7-point scale):

1. I understand enough about engineering to feel confident about working with the U.K. team.

2. I feel uncertain about being able to work effectively with engineering teams. (Reverse coded)

3. I am confident that my business knowledge will make a positive contribution to the engineering teams.

Postproject Survey Items (7-point scale):

1. I now understand enough about engineering to feel confident about working with the U.K. team.

Decision Sciences, Vol 13, No. 2 (April 2015): pg. 121-149. DOI. This article is (C) Wiley and permission has been granted for this version to appear in e-Publications@Marquette. Wiley does not grant permission for this article to be further copied/distributed or hosted elsewhere without the express permission from Wiley. 
2. I am uncertain about being able to work effectively with engineering teams. (Reverse coded)

3. I am confident that my business knowledge made a positive contribution to the engineering teams.

Paired t-tests were conducted to determine whether the collaborative project was effective in reducing uncertainty and increasing confidence about working in an interdisciplinary setting. tTests were also conducted to determine if business students perceived that they had positively contributed to the engineering teams. Results are presented in Table $\underline{5}$.

Table 5. Confidence in interdisciplinary engagement

\section{Pre- Posttest Mean Std. Confidence Test \\ Mean Mean Diff Dev t-Stat Interval \\ $(95 \%)$}

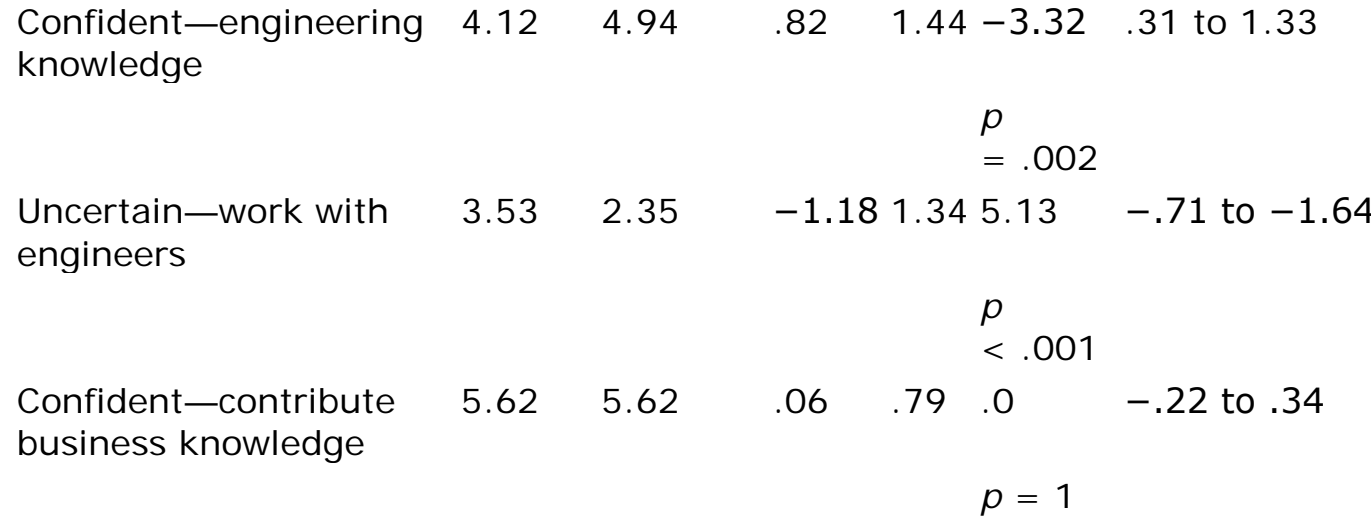

The mean increase in confidence in working with engineering students $(\mathrm{M}=.82, \mathrm{SD}=1.44)$ was significantly greater than zero $(\mathrm{t}=$ -3.32 ; two-tail $p=.002$ ), providing initial evidence that the project was effective in increasing the confidence of business students in working with engineers. This was supported by significant reductions in student uncertainty about working with engineers $(M=-1.18$; SD $=1.34, \mathrm{t}=5.13, \mathrm{p}<.001)$. With the third question, as anticipated, from the start, business students were confident about their ability to contribute to the project, and the engineers, through their business knowledge. Their preproject perceptions were high and remained so till project completion. As such, no significant differences were observed

Decision Sciences, Vol 13, No. 2 (April 2015): pg. 121-149. DOI. This article is (C) Wiley and permission has been granted for this version to appear in e-Publications@Marquette. Wiley does not grant permission for this article to be further copied/distributed or hosted elsewhere without the express permission from Wiley. 
in pre- and postmeans $(M=.06 ; S D=.79 ; t=0 ; p=1)$ of this measure.

While quantitative measures provided empirical support for effectiveness of the collaboration, better insights into the engagement came from student reflections and interactions with faculty. Interdisciplinary collaboration raises disciplinary tension. U.S.-U.K. faculty welcome these challenges as a positive sign that students are engaging with the project and learning from it. As an illustration of such tension, below is an issue raised by a U.S. student via e-mail:

Hello Dr. _US Faculty_,

Last week we discussed the problems with the costing and profitability of our project. I attached the cost of our solar car that [UK] provided. Summary of discussion: [UK] wants to sell 60,000 units, and our group is forecasting approximately 2,000 units. [UK] based their number off the total population of 11 to 13 year old students in the United States. Our group based our numbers on the amount of middle schools multiplied by average unit per school demand.

We have recently discovered that the solar panels are going to cost $\$ 12.55$, instead of $\$ 5$. The fixed cost structure will drastically increase because the fixed cost are divided by 60,000 units. Finally, we were expecting to sell the kit around $\$ 75$ to $\$ 100$ per unit, but based off the aesthetic value, it appears that it will be difficult to sell the kit over $\$ 50$, which makes it difficult to include overhead and administrative costs in the project.

All in all, it has been difficult to explain to our [UK] group that the feasibility of profitability in this project is slim.

The student was advised to revisit their own (U.S. team's) assumptions, and if they held ground, to present objective data to their U.K. partners and convince them. The U.S. students found an issue with their parameters, modified the sale potential to 40,000 units, and presented this to the U.K. team members. The teams jointly reworked the analysis via VC to settle on projected sales of 43,000 units. This is the type of deliberate tension that faculty expect to observe so that students critically question assumptions and resolve issues agreeably when misalignments occur. While the above relates

Decision Sciences, Vol 13, No. 2 (April 2015): pg. 121-149. DOI. This article is (C) Wiley and permission has been granted for this version to appear in e-Publications@Marquette. Wiley does not grant permission for this article to be further copied/distributed or hosted elsewhere without the express permission from Wiley. 
to one incident, such issues arise numerous times over a semester. Most students soon recognize the value of interdisciplinary conflict and related learning opportunities, as highlighted in student reflections below.

... working with engineers, although challenging at times, is also a great benefit.... The most difficult part of the process is helping the [UK] team understand the common business vernacular. Additionally, some cultural differences have been difficult, such as the definitions for robust, sustainable, and durable. [US Student]

... Communication was found to be a crucial part of the project as ... it allowed the UK team to interact with the US team and aid one another in their work ... the UK had little experience with marketing and finance but the US team were able to aid them in this manner thus allowing the UK team to overcome its main shortcoming. [UK student]

... I just sort of assumed that everyone has a business mindset and understand when certain pieces of the process fit in...I thought engineering was a completely separate function who developed models, determined feasibility, and selected materials, but now realize they need to understand certain aspects of their market before they can even begin to develop ideas. Similar to my thinking, our [UK] team did not realize how much customer analysis must take place in order to develop a product. [US Student]

\section{Confidence with Remote Team Collaboration and Technologies}

Three groups of business students (Fall 2011, Spring 2013, and Spring 2014) responded to a set of pre- and postproject survey questions relating to their comfort with remote teams and collaborative technologies. Ninety-eight usable responses were obtained after seven were excluded due to incomplete or missing responses. Students responded to the following questions:

Preproject Survey I tems (7-point Likert scale):

1. I feel comfortable about working with a remote U.K. team.

Decision Sciences, Vol 13, No. 2 (April 2015): pg. 121-149. DOI. This article is (C) Wiley and permission has been granted for this version to appear in e-Publications@Marquette. Wiley does not grant permission for this article to be further copied/distributed or hosted elsewhere without the express permission from Wiley. 
2. I feel comfortable about the technology I will use to communicate with my U.K. teams.

Postproject Survey Items (7-point Likert scale):

1. By the end of this project, I was comfortable about working with the remote U.K. teams.

2. I felt comfortable about the technologies that my team used to communicate with U.K. teams.

Table $\underline{6}$ presents results from paired t-tests of the above measures. Results confirmed that the project was effective in increasing the business students' comfort with working with remote teams (mean difference of .57 was significant at $p<.001$ ) as well as with collaborative technologies used to conduct this work (mean difference of .52 was significant at $p<.001$ ). Most U.S. and U.K. teams have no previous experience with virtual teams. However, it takes only a few sessions to put them at ease with mediated communications. In the first two sessions, teams are overwhelmed by the VC facilities: two projection screens, cameras, microphones, and integrated presentation equipment. This is soon mitigated as teams focus on building relationships, document exchange, etc.

Table 6. Comfort with remote team work

\begin{tabular}{|c|c|c|c|c|c|c|}
\hline & \multirow{2}{*}{$\begin{array}{l}\text { Pre- } \\
\text { Test } \\
\text { Mean }\end{array}$} & \multicolumn{3}{|c|}{ Posttest Mean Std. } & \multirow[b]{2}{*}{ t-Stat } & \multirow{2}{*}{$\begin{array}{l}\text { Confidence } \\
\text { Interval } \\
(95 \%)\end{array}$} \\
\hline & & Mean & Diff & Dev & & \\
\hline \multirow[t]{2}{*}{$\begin{array}{l}\text { Comfort-remote } \\
\text { team }\end{array}$} & 5.41 & 5.98 & .57 & 1.36 & -4.15 & .29 to .85 \\
\hline & & & & & $\begin{array}{l}\mathrm{p} \\
<.001\end{array}$ & \\
\hline \multirow[t]{2}{*}{$\begin{array}{l}\text { Comfort- } \\
\text { technologies }\end{array}$} & 5.66 & 6.18 & .52 & 1.24 & -4.16 & .27 to .77 \\
\hline & & & & & $\begin{array}{l}\mathrm{p} \\
<.001\end{array}$ & \\
\hline
\end{tabular}

A positive virtual presence seems to emerge quickly as students from both locations recognize the value of VC in facilitating communication. There is also a degree of social responsiveness among teams, engendered by the desire to work successfully with remote teams. The technology recedes into the background, and students

Decision Sciences, Vol 13, No. 2 (April 2015): pg. 121-149. DOI. This article is (C) Wiley and permission has been granted for this version to appear in e-Publications@Marquette. Wiley does not grant permission for this article to be further copied/distributed or hosted elsewhere without the express permission from Wiley. 
begin focusing on the normal logistics of teamwork, such as identifying communications liaisons and processes, planning work, and allocating responsibilities. Social cues are experienced despite technology mediation, as reflected below:

It became evident that [ " $X$ "] had become the team coordinator for team USA. We agreed that anything that required to be dealt with the week before our meeting would be relayed to the local teams via me and [team member]. [UK student]

While VC sessions are most useful for developing team trust and communications in these early interactions, students gradually began using a range of communication media to enable better relationship management and work execution. In the comment below, a student relates her team experiences with only minimal reflection on technology:

Our relationship has definitely gotten better even though it has been beneficial and positive from the beginning. There are several reasons for this growth. One is both team's ability to work hard and put out quality work at deadlines ... Another reason is that we respect each other. I think from the first meeting, we established a friendship which led to mutual respect. We are always receptive to each other's ideas for improvement as well, and have never had intense conflicts. One more reason growth has occurred is because we have active communication between groups between video conferences. We set clear goals and expectations that are taken care of before group meetings so we can move forward in our work when we actually see each other. [US Student]

Students discover that compared to local team interactions, technology-mediated communication is limited, and that social responsiveness, relying as it does on mutual trust, is a fragile entity. Many teams identify the need for more face-to-face communication. For example:

On reflection more video conference time or skyping would have helped both groups and the team over all. A more relaxed relationship could have been formed; also team members who weren't really contributing may have opened up in a more relaxed situation. [UK Student]

Decision Sciences, Vol 13, No. 2 (April 2015): pg. 121-149. DOI. This article is (C) Wiley and permission has been granted for this version to appear in e-Publications@Marquette. Wiley does not grant permission for this article to be further copied/distributed or hosted elsewhere without the express permission from Wiley. 
The relationship with our American colleagues wasn't as good as the relationship maintained within our side of the group (UK Members) and I believe this was due to only meeting our American colleagues once a week for a brief 20 minute period through the video conference software. I felt the relationship wasn't as good as we didn't hear our American colleagues daily where as we saw our side of the group members daily in classes etc. [UK Student]

\section{Perceived Team Dependency}

A well-designed interdependent collaboration should enhance student perceptions of mutual and positive dependency. To this end, students should perceive each member's efforts as necessary for the group to succeed, and recognize the unique contribution of each team component toward the creation of a successful group work product (Johnson et al., 1998). For three semesters, this mutual dependency has been assessed as part of the U.S.-teams' reflections. Business students were asked to respond to three survey questions (7-point scale) embedded in their reflections, and designed to evaluate perceived dependency between U.S. and U.K. teams. The specific questions, repeated on each of the five reflections, are

1. Our project's success depends upon strong collaboration between business and engineering teams.

2. Over the remaining weeks, U.K. teams will need us to accomplish their project successfully.

3. Over the remaining weeks, we will need the U.K. teams to accomplish our project work successfully.

For 98 business students (Fall 2011, Spring 2013, and Spring 2014) Figure 4 shows the variation in students' perceived dependency throughout the project. The results were interesting in several ways. First, although minor variations occurred during the semester, perceived mutual dependency (Depend Mutual) remained quite high from start (Mean $=6.37$ ) to end (Mean $=6.22$ ). Around reflection 2 (R2), when engineering students shifted focus to product design and business students researched markets and developed project plans, perceived dependency, as expected, declined. Around reflection R4, the anticipated upswing in value was observed as the teams started to assemble their business plans and final presentations based on

Decision Sciences, Vol 13, No. 2 (April 2015): pg. 121-149. DOI. This article is (C) Wiley and permission has been granted for this version to appear in e-Publications@Marquette. Wiley does not grant permission for this article to be further copied/distributed or hosted elsewhere without the express permission from Wiley. 
technical concepts, product pricing, and marketing strategies. Most interesting was the significant increase in the dependency of U.S. students on their U.K. cohorts (Depend U.S. on U.K.) around reflection R3. While some of this may be self-efficacy issues considering an engineering project, if the same survey was delivered to U.K. students, we suspect that similar results might emerge. Overall, student responses point squarely to the successful creation of a mutually dependent, interdisciplinary project.

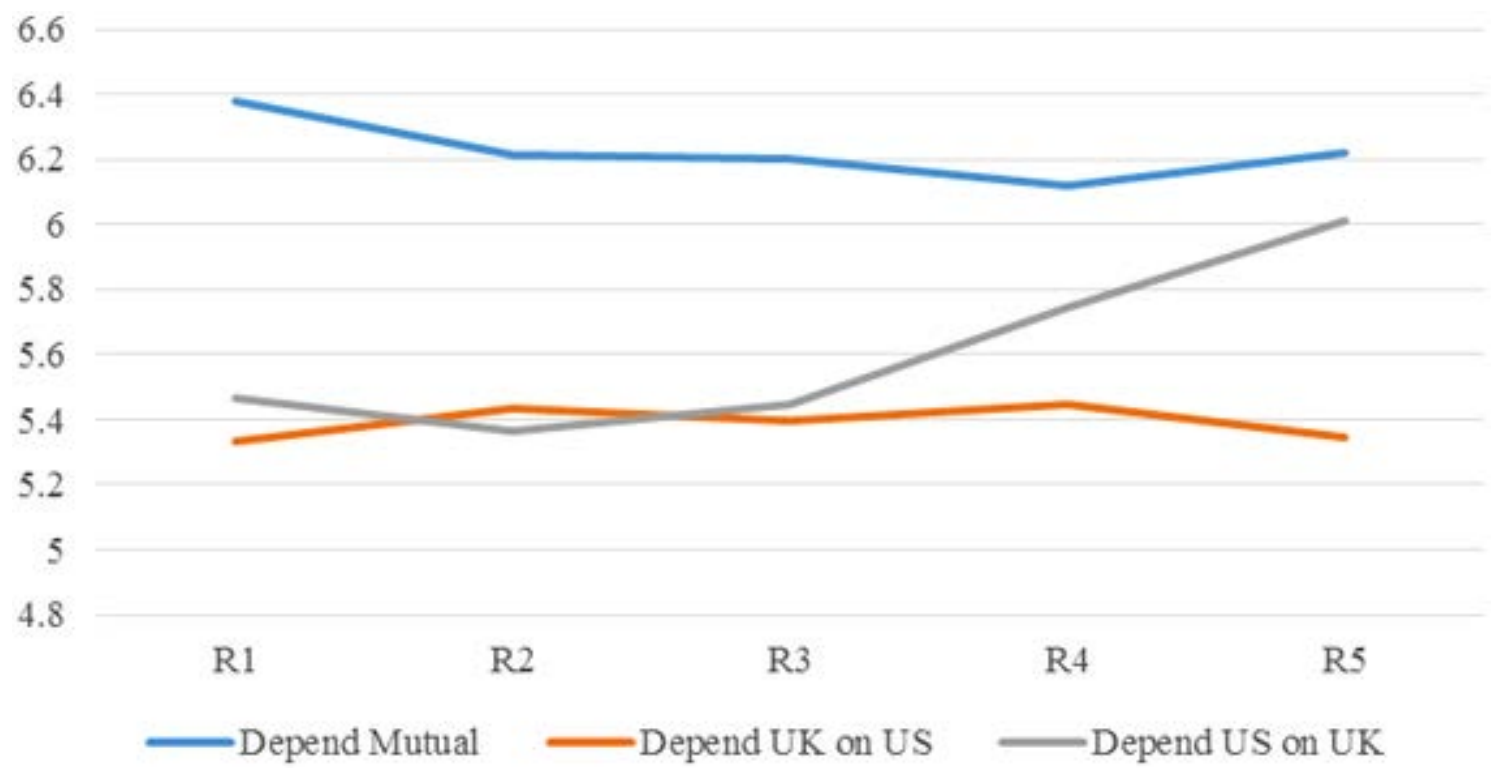

Figure 4. Perceived team dependency-United States.

\section{Secondary Outcomes}

Class observations and reflections point to several other secondary but important benefits, including an improved understanding of cultural, time zone, and systematic differences. The impact of time zone differences on team work dawns on participants, often around key deliverables, and always around changes in daylight savings times. When asked to consider how U.K. members' remoteness impacted their work strategy, a student reflected

I always had to think a few days ahead about what had to get done. [UK] had to be informed a few days before the meeting what was expected of them, and we had to accomplish our tasks ahead of time in case we had any questions for [UK] before

Decision Sciences, Vol 13, No. 2 (April 2015): pg. 121-149. DOI. This article is (C) Wiley and permission has been granted for this version to appear in e-Publications@Marquette. Wiley does not grant permission for this article to be further copied/distributed or hosted elsewhere without the express permission from Wiley. 
deliverable date. Because reaching them was not immediate, last minute questions were not an option. I did not think about this before the project started. I could get away with last minute changes to group projects at [US], but definitely not with [UK]. [US Student]

Working on the U.S.-U.K. project reinforces differences in metric systems. In response to a reflection related to a specific challenge they recently encountered on a project, a student commented

One way it is definitely challenging is developing a product for two different countries; costing is in different currency, target markets were hard to develop, and risks increased. [US Student]

Although cultural differences most often confront teams in the form of accent and language syntax, subtle distinctions such as perceived value of time and deadlines emerge as teams work together over prolonged periods.

Based on faculty observations, the project outcomes provide an ongoing reminder to participants of social responsibility surrounding their collaboration. The projects require students to translate social responsibility into disciplinary terms, specifically product features and ease of use for the target market, appropriate product pricing for a new and growing market, and integrating responsible marketing strategies. Fall term students recognized financial and healthcare pressures on the buying power of parents of disabled children, while Spring term participants considered resource constraints on investing in renewable energy. The research required, for example, market demographics, competitor products, understanding renewable energy or disabilities, engaging students in increasing their awareness around these societal issues.

\section{Limitations of Surveys and Reflections}

Although term-based surveys and reflections are effective tools for obtaining developmental insights into the teaching environment, they are a self-reported and potentially biased reflection of student learning. As classroom and project facilitators, we have observed some students who practiced good project and team management formally

Decision Sciences, Vol 13, No. 2 (April 2015): pg. 121-149. DOI. This article is (C) Wiley and permission has been granted for this version to appear in e-Publications@Marquette. Wiley does not grant permission for this article to be further copied/distributed or hosted elsewhere without the express permission from Wiley. 
through the U.S.-U.K. setting, but when presented with projects outside of this collaboration, tended to revert to former ways by not developing plans or inserting rigor into their analysis. This is symptomatic of short-term, task-focused learning, and this sort of learning may be reflected in surveys and reflections. However, it is also true that students who have experienced this offering and entered industry report the usefulness of the range of skills promoted through the collaboration.

An ideal assessment of learning would involve a dual, long-term strategy. First, prior to graduation, participants' application of concepts learned through this class may need to be examined longitudinally on other projects. U.S. participants typically take a project-driven capstone class subsequent to the offering described in this study. U.K. students undertake an individual project in the fourth year of their honors level program, and subsequently undertake a group project in their fifth year (Masters level). These classes provide an ideal opportunity to apply team and/or PM principles learned via the U.S.U.K. collaboration. They may be a more ideal setting for conducting assessment related to long-term learning.

A second longitudinal approach to learning assessment could utilize focus groups or interviews of participants who have completed the course within the last year. This may include current students who have had the opportunity to apply lessons from the U.S.-U.K. collaboration to other similar projects, or alumni who can reflect on the pragmatic application to their employer organizations. Informal conversations with alumni suggest that this might be a more desirable option. As we have not acquired formal longitudinal data for this study, we highlight this as a limitation as well as an opportunity for future pedagogical research.

\section{Recommendations For Transferability}

Reflections offered offer an opportunity to generate lessons learned through an engagement. In order to promote transferability of our teaching environment, in this section, we share some such lessons gathered through our 6 years of engagement.

Decision Sciences, Vol 13, No. 2 (April 2015): pg. 121-149. DOI. This article is (C) Wiley and permission has been granted for this version to appear in e-Publications@Marquette. Wiley does not grant permission for this article to be further copied/distributed or hosted elsewhere without the express permission from Wiley. 


\section{Mutually synergistic partnership}

A committed and synergistic arrangement between collaborating faculty is the most critical success factor. Both must share responsibility for success of the learning environment and its continuous improvement. Goals and objectives must be aligned while accommodating each subject's unique disciplinary needs. The U.S.U.K. partnership was initiated through a posting on ISWorld, a listserv maintained by the Association of Information Systems (AIS). Although the U.S. faculty received numerous global responses to the post, U.K. faculty responded most proactively by setting up a phone meeting within the first day. Once initial interests were exchanged, a series of e-mails and phone calls were used to detail out the collaboration. This set the tone for long-term engagement. Collaborators must be responsive. The collaborating faculty have engaged only via computer mediation. Yet, faculty partners are cohesive and trust each other, exemplifying good practice for students. Other instructors considering such collaboration might leverage existing partnerships or communities of practice to identify potential partners.

\section{Managing significantly diverse teams is easier than thought}

The significant diversity of teams often raises concerns about the transferability of this initiative. At one level, the concern is valid as greater effort is required to set up team interactions as faculty must agree on interdependent pedagogical goals, design mutually synergistic roles for teams and themselves, provide nonconflicting communications to students, and be more responsive than normal. Although this takes work, based on our experience, significantly diverse teams present greater opportunities for the design of innovative, interdependent processes than similar teams. The U.K.U.S. offering was developed such that teams had distinct but synergistic roles. Such interdependency may also be developed between industrial engineers and supply chain majors in designing logistics/inventory management solutions, marketing or finance students working with engineers in similar roles as U.S. teams did, or medical students collaborating with engineers and/or business students to analyze and design healthcare solutions. If faculty are

Decision Sciences, Vol 13, No. 2 (April 2015): pg. 121-149. DOI. This article is (C) Wiley and permission has been granted for this version to appear in e-Publications@Marquette. Wiley does not grant permission for this article to be further copied/distributed or hosted elsewhere without the express permission from Wiley. 
committed to continuous improvement, in our experience, the most important design elements fall into place within three offerings, after which minor efficiencies occur from sustained efforts.

\section{Technological transferability}

Not all institutions have access to extensive VC facilities. However, a range of options are now available to support pedagogical collaboration. Desktop-based Polycom roundtable, active speaker cameras can support large group VC sessions using Skype or Microsoft Lync. Adobe Connect, Google Hangouts, and TeamViewer present other economical alternatives. Skype has been used successfully as an alternate to large conference-style VC facilities, and provides students with comparative experience. It is easier to achieve technological compatibility across remote locations than ever before. Technology is not a limitation, although our own initiatives and vision might be.

\section{Consider executing small projects first}

To ease into an extensive offering, faculty could consider starting with a small team task and evolve toward a full project. For instance, virtual teams could initially work on a small presentation developed jointly over a 1- to 2-week window, such as analyzing national marketing and product development strategies of a global firm (e.g., GE, Apple). The following semester could involve a 3- to 4week engagement, enabling faculty to test and adapt working relationships, technical feasibility, and course level synergy.

\section{Manage student expectations early but provide guidance}

A significant aspect of initial faculty communication must be directed to preparing students to work independently from faculty to maximize learning and enhance problem solving. These expectations should be managed early in the term. While describing the project during early weeks, U.S. and U.K. faculty often highlight our inability to control significant aspects of the project, for example, team personalities, trust and comfort, and the effectiveness of technology mediation. Students, in such circumstances, become willing partners in 
identifying opportunities for continuous improvement in a noninvasive manner. Faculty must, however, be prepared to play a greater advisory role for students as compared to traditional classes.

\section{Highlight business and engineering synergy outside the project}

Most students recognize interdisciplinary differences in their interactions. However, not all students recognize this quickly enough. To this end, faculty can reinforce through case studies and news items how these synergies are integral to the business and engineering worlds, and critical to the success of many products consumed by students. Such discussions trigger greater reflection among students about how their own projects have evolved, or should evolve, to be successful. Faculty might assign students a particular product to discuss how business and engineering integrate to make the product a success. Failed products are equally effective in driving home the point.

\section{Role definition is important}

Anecdotally, we have experienced the usefulness of role-playing in student engagement for projects such as these. Student roles give shape to their interactions. For example, during one term, U.S. teams were told they were project managers, and their task was to manage the project to completion. This was different from other semesters in which they were considered part of joint teams who were to pitch a startup company with an idea based on the product they were designing. In that one semester, while U.S. students took the role of PM seriously, they were less engaged with developing the business case, and shifted the onus onto the U.K. teams, undermining the benefits of the collaboration. We recommend that faculty set the student roles around course objectives that they expect to accomplish.

\section{Conclusion}

Interdependent, interdisciplinary teaching initiatives are imperative in light of the rising integration of business and technical functions. The U.S.-U.K. initiative has demonstrated that with

Decision Sciences, Vol 13, No. 2 (April 2015): pg. 121-149. DOI. This article is (C) Wiley and permission has been granted for this version to appear in e-Publications@Marquette. Wiley does not grant permission for this article to be further copied/distributed or hosted elsewhere without the express permission from Wiley. 
thoughtful and sustained delivery, higher education can effectively support this workplace need. For this to be engendered effectively, several levels of engagement are necessary. First, students must be better prepared to face the ambiguities and uncertainties that such pedagogy offers. This preparation must begin in students' first year of university education during which higher and more rigorous expectations need to be developed than currently. Second, faculty must continue to reinvent themselves and demonstrate the entrepreneurial spirit expected of students. To this end, while the transformational experiences for U.S.-U.K. teams are still emerging, we expect that with industry, student, and faculty commitment to continuous learning, such offerings will deliver sustained value. Finally, and most critically, higher education institutions must be willing to invest in such initiatives, through faculty support and resources, to upholding standards necessary to deliver such programs. Without this three-pronged motivation, any such innovations will be difficult to sustain beyond individual faculty motivations.

1. Full Business Case template and other instructions for the US teams can be obtained from the first author.

\title{
Appendix A
}

\section{Engineering Module Handbook: Fall Semester Offering}

\author{
Group Work
}

This is a group project. The group will comprise some team members in (United Kigdom) and additional members in (United States). Interaction between the two segments of the group, in (United Kingdom) and (United States), are the responsibility of the team. Regular video conference facilities will be provided but other interaction is at the teams' discretion.

The subgroup in (United Kingdom) will be expected to:

a) meet regularly,

b) provide evidence of the development of the project through minutes logged on the (U.K.) Blackboard (Bb) site for this module,

Decision Sciences, Vol 13, No. 2 (April 2015): pg. 121-149. DOI. This article is (C) Wiley and permission has been granted for this version to appear in e-Publications@Marquette. Wiley does not grant permission for this article to be further copied/distributed or hosted elsewhere without the express permission from Wiley. 
c) give a group presentation of the outcomes of the project, and

d) write an individual reflective log to demonstrate their individual understanding of their place within the team and their development through team working.

There will be peer assessment, where each group member will evaluate the performance of their teammates, including themselves.

The Project

As a team you must:

a) undertake a feasibility study for a new product to match the design brief outlined below, the documentation provided at the project's end will comprise a product specification and a commercial justification for its further development; and

b) provide a "reflective technical study" about the new product and the pathway you chose to arrive at a conclusion.

You should work as a joint team, that is, not only with colleagues in (United Kingdom) but also in close collaboration with your international teammates. Make sure that you understand the relationship between your part of the project and theirs. You should:

1) Devise several possible concepts for the product, then create a detailed concept design for the product and have it fully costed. This will include materials, manufacturing process, and labor needed to make it.

2) Decide the commercial potential of the product, identifying selling price and sales volume

The product brief: “Inclusive Design."

An ethical company has been approached to develop a toy that can provide physical and cognitive development for disabled children. The initial product is aimed at a child who has cerebral palsy. The condition means that the child has full brain functions but is unable to speak and unable to control his/her limbs. Children with this condition do, however, have control of their head and are able to move their head in different directions as they need to. This will allow the child to use the head to "control" the actions of the toy through interacting 
with two sensors. A 12-year-old child has limited ability to control body movements, they have macro control of head movements but not micro control.

The child sits in a chair with a headrest that forms a " $U$ " around his head. Sensors could be mounted in this "U." Your brief is to devise an electromechanical game, preferably for two or more players, which will allow the child to develop and to enjoy a more normal interaction with other children and adults. I deally the activity developed could be adapted to cater for other disabilities by suitable redesign of the sensor interface.

One restriction: The product to be invented should not be a computer game, as these are already available and require little in the way of electromechanical design.

Note: During the product specification, the team will have to take into account and understand the interests and capabilities of 6-year-old children.

Deliverables

1. Presentation-Worth $20 \%$. This presentation should sell your product idea as it were, in a dragon's den situation. It should demonstrate equal contributions from the team members.

2. Reflective technical assessment-Worth $40 \%$ of your marks. To be submitted on or before (date). Late submissions will have marks deducted at the rate of $10 \%$ per day. A specification will be placed on $\mathrm{Bb}$ by the end of (date).

3. All project information, including the presentation to be lodged on $\mathrm{Bb}$ by (date). Marks awarded for the information on $\mathrm{Bb}$ :

a) quality of the information in the group pages, $15 \%$;

b) quality of the analysis, based on the information, that is placed on $\mathrm{Bb}, 15 \%$; and

c) your own personal contribution to the material on $\mathrm{Bb}$, $10 \%$.

In assessing the actual mark, note will be taken of the timely addition of the material to $\mathrm{Bb}$. Deposition of material and analyses overly skewed to the end of the project will be considered unfavorably.

Decision Sciences, Vol 13, No. 2 (April 2015): pg. 121-149. DOI. This article is (C) Wiley and permission has been granted for this version to appear in e-Publications@Marquette. Wiley does not grant permission for this article to be further copied/distributed or hosted elsewhere without the express permission from Wiley. 


\section{Appendix B}

\section{Format of Business Case $\underline{1}$}

1. 1-page executive summary

2. Problem statement

3. Goals and objectives

4. Expected benefits

5. Expected limitations

6. Customer characteristics

7. Competitor analysis

8. Project plan including project schedule and resource requirements

9. Costs and pricing

10. Breakeven analysis

11. Major risks

12. Marketing plan (1-2 pages)

13. Appendix, which must include product images, technical details, and details of cost analysis.

\section{Biographies}

Monica Adya is an associate professor of management at Marquette University. She received her PhD in Management Information Systems from The Weatherhead School of Management, Case Western Reserve University. Monica publishes in primarily two research areas: (a) IT workforce spanning themes related to diversity in the workplace, offshore team management, and workforce planning; and (b) knowledge-based systems with applications to business forecasting. Monica teaches Systems Analysis and Design and Project Management, the latter with an offshore emphasis. To facilitate this, she has collaborated with faculty in India, Canada, and Scotland. Monica has published in several journals including Decision Sciences J ournal of Innovative Education, Human Resource Management, International Journal of Forecasting, Information Systems Research, IT \& People, and Journal of Global Information Management.

Bryan Temple, BTech (Hons), PhD, CEng, MIET, retired in August 2012. Prior to that, he worked at Glasgow Caledonian University in Scotland teaching engineering design and business for engineers. He has been involved with interdisciplinary project teaching for more than 15 years and has collaborated with both

Decision Sciences, Vol 13, No. 2 (April 2015): pg. 121-149. DOI. This article is (C) Wiley and permission has been granted for this version to appear in e-Publications@Marquette. Wiley does not grant permission for this article to be further copied/distributed or hosted elsewhere without the express permission from Wiley. 
the United States and many European countries using various communication techniques. He has had visiting lecturer posts in France, Germany, and Russia. Prior to joining the university in 1992, he had worked as an industrial researcher and has been a director of two companies: designing both microfilm equipment and production machines for the electronics industry. He continues to play: designing toys for disabled children.

Donald M. Hepburn is a senior lecturer in the School of Engineering and Built Environment at Glasgow Caledonian University (GCU). While maintaining research interest in condition assessment of insulation materials and in partial discharge degradation for HV/MV plant diagnostics, he has been active in pushing forward interdisciplinary teaching and learning and in making education industrially relevant. He has been involved in multidisciplinary teaching with universities in United States and Finland for a number of years and in a European Union-funded assessment of "Competences for Competitiveness." He is a member of the Universities High Voltage network (UHVnet) in the United Kingdom and of CIGRE working groups. Dr Hepburn holds a $\mathrm{BA}$ (hons) from the Open University and a PhD from GCU, he is a member of IEEE, IET, and Institute of Physics.

\section{References}

Adya, M., Nath, D., Sridhar, V., \& Malik, A. (2008). Bringing global sourcing into the classroom: Lessons from an experiential software development project. Communications of the AIS, 22(2), 33-48.

Arnold, U. (2000). New dimensions of outsourcing: A combination of transaction cost economics and the core competencies concept. European J ournal of Purchasing and Supply Management, 6(1), 23-29.

Barki, H., \& Pinsonneault, A. (2005). A model of organizational integration, implementation effort, and performance. Organization Science, 16(2), 165- 179.

Chau, K. W. (2007). Incorporation of sustainability concepts into a civil engineering curriculum. Journal of Professional Issues in Engineering Education and Practice, ASCE, 133(3), 188-191

Dyke, J., \& Wojahn, P. (2000). Getting "dissed": Technical communicators in Interdisciplinary Engineering. Proceedings of the IEEE Professional Communication Society International Professional Communication Conferences \& Proceedings of the 18th Annual ACM International Conference on Computer Documentation: Technology \& Teamwork. Cambridge, MA, Piscataway, NJ, USA: IEEE Educational Activities Department, 7-23.

Decision Sciences, Vol 13, No. 2 (April 2015): pg. 121-149. DOI. This article is (C) Wiley and permission has been granted for this version to appear in e-Publications@Marquette. Wiley does not grant permission for this article to be further copied/distributed or hosted elsewhere without the express permission from Wiley. 
Ford, R. M., Goodrich, J. G., \& Weissbach, R. S. (2004). A multidisciplinary business and engineering course. $34^{\text {th }}$ ASEE/IEEE Frontiers in Education Conference, October 20-24, Savannah, GA, Piscataway, NJ, USA: IEEE Educational Activities Department.

Foundation Coalition. (2014). Positive interdependence, individual accountability, promotive interaction: Three pillars of cooperative learning ( http://www.uwstout.edu/soe/profdev/resources/upload/acl_piiapi.pdf ).

Housely, W. (2003). Interaction in multidisciplinary teams. Hants, England: Ashgate Publishing Co.

Johnson, R. T. Johnson, D. W., \& Holubec, E. J. (1998). Cooperation in the classroom, Boston, MA: Allyn \& Bacon.

Klein, J. T. (1995). Interdisciplinary and adult learners. The J ournal of Graduate Liberal Studies, 1(1), 113-126.

Long, S. K. \& Carlo, H. J. (2013). Collaborative teaching and learning through multi-institutional integrated group projects. Decision Sciences J ournal of Innovative Education, 11(3), 233-241

Long, S., Moos, J. C., \& Ridic, A. B. (2012). The role of multi-institutional partnerships in supply chain management course design and improvement. Journal of Education for Business, 87(1), 129-135.

Maleki, R. A. (2009) Business and industry project-based capstone courses: A reflection on the performance of student teams. Industry and Higher Education, 23(2), 103-110.

Metros, S. E. (2005). Visualizing knowledge in new educational environments: A course on learning objects. Open Learning, 20(1), 93-102.

Miller, R. L., \& Olds, B. M. (1994). A model curriculum for a capstone course in multidisciplinary engineering design. J ournal of Engineering Education, 84(4), 311-316.

Millis, B., \& Cottell, P. (1997). Cooperative learning for higher education faculty. Phoenix, AZ: Series on Higher Education, Oryx Press.

Newell, J. A., Marchese, A. J., Ramachandran, R., Sukumaran, B., \& Harvey, R. (1999). Multidisciplinary design and communication: A pedagogical vision. International J ournal of Engineering Education, 15(5), 376382.

O'Brien, W., Soibelman, L., \& Elvin, G. (2003) Collaborative design processes: An active-and-reflective learning course in multidisciplinary collaboration. Journal of Construction Education, 8(2), 78-93.

Okudan, G. E. \& Zappe, S. E. (2006). Teaching product design to nonengineers: A review of experience, opportunities, and problems. Technovation, 26(11), 1287-1293.

Decision Sciences, Vol 13, No. 2 (April 2015): pg. 121-149. DOI. This article is (C) Wiley and permission has been granted for this version to appear in e-Publications@Marquette. Wiley does not grant permission for this article to be further copied/distributed or hosted elsewhere without the express permission from Wiley. 
Olson-Buchanan, J. B., Rechner, P. R., Sanchez, R. J., \& Schmidtke, J. M. (2007). Utilizing virtual teams in a management principles course. Education \& Training, 49(5), 408-423

Pinto, M. B., Pinto, J. K., \& Presoctt, J. E. (1993) Antecedents and consequences of project team cross-functional cooperation. Management Science, 39(10), 1281-1297

Powell, A. Piccoli, G., \& Ives, B. (2004). Virtual teams: A review of current literature and directions for future research. The DATABSE for Advances in Information Systems, 35(1), 6-36.

Ropers-Huilman, B., Carwile, L., \& Lima, M. (2005). Service learning in engineering: A valuable pedagogy for meeting learning objectives. European J ournal of Engineering Education, 30(2), 155-165.

Rosca, D. (2005) Multidisciplinary and active/collaborative approaches in teaching requirements engineering. European Journal of Engineering Education, 30(1), 121-128.

Rosenfield, P. L. (1992). The potential for transdisciplinary research for sustaining and extending linkages between health and social sciences. Social Science and Medicine, 35, 1343-1357.

Rusu, A., Rusu, A., Docimo, R., Santiago, C., \& Paglione, M. (2009). Academia-academia-industry collaborations in software engineering projects using local-remote teams. SIGCSE, March 3-7, 301-305.

Ryssen, S.V. \& Godal, S.H. (2000). Going international without going international: Multinational virtual teams. Journal of International Management, 6(1), 49-60.

Temple, B.K. \& Allan, M. (2000) Engineers and business: Spanning the divide by means of cross-disciplinary activities. British J ournal of Engineering Education, 1(1), 1470-4692

Wellington, P., Thomas, I., Powell, I., \& Clarke, B. (2002). Authentic assessment applied to engineering and business undergraduate consulting teams. International J ournal of Engineering Education, 18(2), 168-179.

Winn, B. \& Heeter, C. (2006). Resolving conflicts in educational game design through playtesting. Innovate, 3(2), (http://www.innovateonline.info/).

Wojahn, P., Dyke, J., Riley, L. A., Hensel, E., \& Brown, S. C. (2001). Blurring boundaries between technical communication and engineering: Challenges of a multidisciplinary, client-based pedagogy. Technical Communication Quarterly, 10(2), 129-148.

Zavbi, R., \& Tavcar, J. (2005). Preparing undergraduate students for work in virtual product development teams. Computers \& Education, 44(4), 357-376.

Decision Sciences, Vol 13, No. 2 (April 2015): pg. 121-149. DOI. This article is (C) Wiley and permission has been granted for this version to appear in e-Publications@Marquette. Wiley does not grant permission for this article to be further copied/distributed or hosted elsewhere without the express permission from Wiley. 